УАК 130.2:008.2

DOI: $10.26565 / 2226-0994-2020-63-2$

\title{
Володимир Прокопенко
}

\section{АЕО ШТРАУС: КРИТИКА ПОАІТИЧНОЇ ФІАОСОФІЇ ГЕГЕАЯ}

Стаття присвячена критиці Аео Штраусом політичної філософії Гегеля. Автор вважає цю тему актуаььню в контексті кризи сучасної політичної науки. А^я осмислення причин і характеру цієї кризи необхідно звернути увагу на деякі альтернативні філософсько-політичні теорії XX сторіччя. Філософія політики Аео Штрауса є саме такою альтернативною теорією. Штраус виступив з радикальною критикою модерної політичної філософії, яку розглядав як важливу складову частину проєкту модерної цивілізації. Штраус вважас, що Гегель став одним із найвизначніших філософів, який брав участь у створенні сучасної науки та всього сучасного світу. Автором розглядаються основні критичні аргументи Штрауса, оцінюеться їхня обгрунтованість та їхне значення Аля штраусіанської консервативної революції у філософії. Особливу увагу автор приділяє питанню про роль Гегеля в розриві з класичною політичною філософією. Штраус звинуватив Гегеля в тому, що той здійснив всі основні кроки, які привели до цього розриву. Гегель, як стверджує Штраус, провів секуляризацію політичного мислення, що привело до втрати універсальних християнських цінностей. НасліАком цієї секуляризації стало домінування позитивізму в політичній філософії. Гегелівська філософія історії, вважає Штраус, є релятивізмом. Історицизм і прогресизм Гегеля є суперечними і непосліАовними. Крім того, Штраус звинувачуе Гегеля у вілмові віА філософського езотеричного мистецтва письма. У статті звертається увага на те, що, попри критичне ставлення до Гегеля, Штраус визнавав його значення і вважав Гегеля виАатним мислителем свого часу. Гегелівську філософію Штраус розгляАав як своєріАну проміжну манку між класичною філософією і сучасним позитивізмом. Автор робить висновок, що Аля Штрауса критика гегелівської політичної філософії стала важливим елементом його проєкту реставрації класичної політичної філософії. У статті використано маловіАомі матеріали мекцій Штрауса 1958 і 1965 року.

КАючові слова: політична наука, класична політична філософія, історицизм, релятивізм, прогресизм, фіналізм, письмо між рялків.

Актуальність статі обумовлена процесами, які віљбувались в галузі політичної філософії протягом останніх сторічь, починаючи з доби Нового часу, і призвели Ао радикальних змін в самих основах філософського мислення про політику. Ці зміни, їхні характер і насліАки, потребували А^я свого осмислення певного критичного віАсторонення віА магістральних напрямків політичної науки. Саме таку позицію зайняли німецькоамериканські філософи Г. Арендт, Е. Фегелін і $\Lambda$. Штраус, які піААали радикальній критиці не просто сучасну науку про політику, а й весь проєкт сучасності. $\Lambda$. Штраус особливу увагу прилілив критиці філософії Гегеля, який був, на його Аумку, одним 3 тих мислителів, які створили модерну філософію і саме суспільство модерну. В останні роки українське суспільство очевиАно потребує нових піАходів Ао осмислення політичних явищ і процесів, оскільки міберальна ідеологія, яка домінувала в світі протягом останніх десятирічь, сьогодні Аемонструє явні ознаки концептуальної і методологічної кризи. 3 огляду на цю ситуацію, звернення до ідей $\Lambda$. Штрауса може Аати поштовх вітчизняній філософсько-політичній Аумці. Це звернення є гостро актуальним, враховуючи те, що жодна робота Штрауса досі не перекладена українською мовою.

Аослідження філософії Аео Штрауса протягом останніх років набули могутнього поштовху завдяки тому, що до наукового обігу були залучені величезні масиви інформації, яка раніше залишалась мало відомою: аудіо записи його мекцій і семінарів, студентські конспекти, спогади про усні бесіди зі Штраусом, інтерв'ю і статті в пресі та на ТБ,

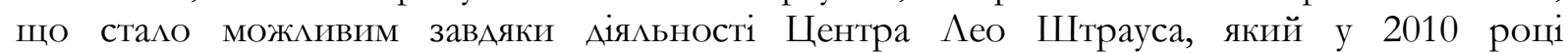
був вілкритий у Чиказькому університеті. Тема критики Штраусом Гегеля та інших модерних філософів посіАає помітне місце в дослілженнях штраусіанства, була опублікована низка статей і монографій, які розкривають цю тему в різноманітних

(C) Прокопенко B. B., 2020.

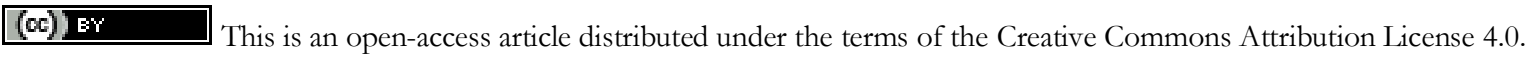


аспектах. Це насампереА статті таких авторів, як В. Альтманн [Altmann, 2007], Р. Піппін [Pippin, 1993], Т. Фулмер [Fuller, 2014], М. ШАі [Schlie, 2013], книги С. МакдональА i Б. Крейга [MacDonald \& Craig, 2014], Т. Пенгла [Pangle, 2006]. На жаль, звернення вітчизняних авторів до теоретичної спадщини Аео Штрауса залишаються одиничними випадками, і ми можемо тут навести тільки статті Амитра Шевчука [Шевчук, 2010] та Ігоря Карівця [Карівець, 2010], а питання про критику Штраусом філософії Гегеля, наскільки нам відомо, взагалі ніким з вітчизняних науковців ще не розглядалось.

Метою статmі є АосліАження основних напрямків штраусіанської критики політичної філософії Гегеля з тим, щоб висвітлити цілі й методи здійснення Штраусом його проєкту реставрації класичної політичної філософії. Аео Штраус - один 3 найвидатніших політичних філософів XX століття, неординарний i суперечливий мислитель, навколо спадщини якого ось уже Аекілька десятиліть ведуться запеклі дискусії. Приводів Аля цих Аискусій безАіч - книги Штрауса сповнені неконвенціональної аргументації і неочевидних висновків. ОАнією з вагомих причин Аля суперечок щодо теорій Штрауса в науковій спільноті стаАа характерна особливість його творчої манери: основним жанром творів Штрауса був критичний коментар, у рамках якого він успішно ухилявся віА прямого викладення своїх іАей і представляв їх у вигляді побічних висновків $з$ аналізу (майже завжди - навмисно тенденційного) творів філософів минулого. Ця стратегія, заснована на штраусіанському «письмі між рядків», завжАи спонукає читача замислитись наА тим, з якою метою Штраус звертається до спаАщини того чи іншого мислителя, аАже автентичне розуміння і об'єктивний історико-філософський аналіз ніколи не були Аля нього головною цілАю Аослідження.

Про Гегеля Штраус згадує неодноразово, називаючи його одним 3 найбільш видатних філософів сучасного світу. «Гегель був найбільш впливовим філософом історії - пише він у роботі «Три хвилі сучасності» [Штраус, 2000, с. 79]. Попри всю увагу й повагу до Гегеля, Штраус не присвятив жодну зі своїх опублікованих робіт власне аналізу гегелівської філософії. Річ у тім, що Штраус до Гегеля звертається виключно в рамках загальної критики сучасності, як до одного із засновників сучасного світу, і критика Гегеля являє собою суттевий елемент штраусіанської консервативної революції в політичній філософіiі. У світлі цього зауваження звернемо увагу на два найважливіших джерела, які Аають змогу зрозуміти сутність критичної позиції Штрауса. Першим є Аистування і обмін полемічними виступами з Олександром Кожевом. 3 Кожевом Штраус був знайомий ще 3 1933 року і про його «Введення до читання Гегеля» він сказав, що це «ОАна 3 найцінніших книг про Гегеля, які він знає» [MacDonald \& Craig, 2014, p. 13]. Важливою обставиною було і те, що Штраус вважав інтерпретацію Кожевом «Феноменології Ауху» поверненням до справжнього Гегеля. СліА, однак, зауважити, що «справжній Гегель» означає в цьому разі не стільки віАповіАність вченню самого Гегеля, скільки згоду з Штраусом на спільному грунті: Кожев визнавав пізніше, що Аивився на феноменологію Гегеля піл впливом гайлепгерівського «Буття i часу», антропології Гайдеггера та його поняття «буття Ао смерті» [Kojève, 1990, s. 32-33]. На початку 20-х років Штраус слухав ГайАеггера у Фрайбурзі (найімовірніше, це були мекції зимового і мітнього семестру 1922 року «Феноменологічні інтерпретації Арістотеля»), тож цей погляА Кожева був Аля нього близьким і зрозумілим. Полеміка почалась у зв'язку з виходом книги Штрауса «Про тиранію», яка спочатку заАумувалася ним як всього мише переклаА Аіалогу Ксенофонта «Гієрон» і коментар Ао нього, але після того, як Штраус запропонував Кожеву прочитати і оцінити рукопис, книга зазнала серйозних трансформацій. У результаті розгорнулася широка Аискусія, в якій Кожев, виступаючи захисником Гегеля, несподівано Аля себе опинився в ролі аАвоката сучасності. Схоже, в цьому і полягав хитрий план Штрауса: змусити гегельянців визнати відповіАальність Гегеля за характер сучасного світу, за всі його проблеми і негаразди. Аискусія виявилась надзвичайно пліАною і цікавою, так що «Про тиранію», починаючи з першого видання, завжди видається разом з коментарем Кожева 
«Тиранія і мудрість» і відповідАю Штрауса. Саме в такому вигляді стає найбільш очевидним протистояння оцінок гегелівської філософії «зліва» (Кожев) і «справа» (Штраус).

Аруге Ажерело, мекції Штрауса про Гегеля, Аовгий час було недоступним через те, що тексти мекцій збереглись виключно у вигляді магнітофонних записів і студентських конспектів та були видані Аруком тільки в 2019 р. [Strauss, 2019a; Strauss, 2019b]. Тому приділимо цьому Ажерелу особливу увагу. $е о$ Штраус Авічі прочитав у Чиказькому університеті курс, присвячений політичній філософії Гегеля - у 1958 і в 1965 роках. Це був не традиційний мекційний курс, а скоріше, ряд теоретичних семінарів, які проводились за загальною програмою. Всього було проведено 14 занять. А^я Штрауса така методика була звичайною, як про це згалували його учні А. БАум, С. Бенардет і С. Розен [Rosen, 2006]. Основним текстом Гегеля Аля аналізу в курсі Штрауса була обрана «Філософія історії». На питання про те, чому він не звернувся до «Філософії права», останньої роботи, особисто підготовленої до Аруку Гегелем, Штраус віАповів, що вважає усні мекції, нехай і в записі студентів, більш цінним Ажерелом, ніж пригладжений редактором письмовий текст.

Штраусіанська інтерпретація політичної філософії Гегеля представлена в цьому курсі в концентрованому вигляді, Штраус включив до неї тези про Гегеля, які вже висувалися ним раніше, протягом декількох попередніх десятиліть. Висновки, зроблені в курсі, ми так само зустрічаємо в пізніх роботах Штрауса. Критичні аргументи Штрауса спрямовані насамперед на критику гегелівського історицизму. Філософія Гегеля, вважає Штраус, найбільш повно і чітко преАстав яе історицизм як оАну 3 Авох головних інтелектуальних сил модерну, що справили руйнівний вплив як на політичне мислення сучасності, так і на всю сучасність загалом. Разом 3 іще однією такою силою, позитивізмом, історицизм намагається Аосягти нейтральності в оцінці суспільства, політики і політичних речей. Але якщо позитивізм домагається цього прагненням Ао голої фактичності, що відкидає іАею БАага (платонівського і арістотелівського $\dot{\alpha} \dot{\alpha} \theta$ оv), то історицизм скасовує класичне політичне філософське мислення тим, що перетворює агатон в обмежені і відносні блага і цінності, які належать певній історичній епосі. Значення цієї трансформації - величезне, вона знаменує розрив з класичною політичною філософією Пцатона і Аристотеля та народження нової політичної науки. На Аумку Штрауса, саме Гегель, хоча той і оцінював класичну політичну філософію Ауже високо, як справжнє філософське мислення, несе найбільшу віАповіАальність за цей розрив. Політична наука модерну, на відміну віА політичної філософії греків, більше вже не

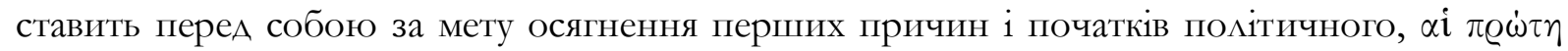

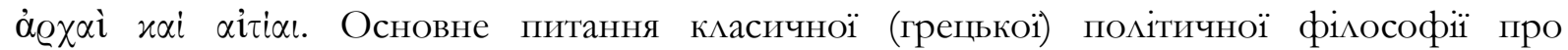
можливість втілення найкращого, справеАливого політичного порядку відтепер замінюеться питанням про можливість якомога кращого, бажаного політичного устрою. Отже, у політичному мисленні модерна метафізика замінюється історією і методологією.

Ще одна принципова віАмінність: класична політична філософія гармонійно поєднува^а високу теоретичність з безпосередньою практичністю. Філософ-метафізик міг бути чинним політиком, i ця участь була не випадковою, а необхіАною Аля філософа, природним виразом його філософської позиції. Штраус зауважує: «успішний пошук мудрості може привести до того, що мудрість - не єАина необхіАна річ» [Штраус, 2007, с. 40]. Аіяльність Архіта в Таренті, Пцатона в Сіракузах і Арістотеля в Пелмі є яскравим тому доказом. У роботі «Що таке політична філософія» Штраус пише: «... політична філософія має справу з політичними справами таким способом, який повинен мати певне відношення до політичного життя; отже, предмет політичної філософії повинен збігатися з метою, з кінцевою ціл^ю політичної лії. Темою політичної філософії є великі цілі людства - свобода і правління або імперія; це цілі, здатні підняти всіх цюдей над їхніми нікчемними Я» [Штраус, 2000, с. 10]. В епоху модерна, навпаки, віАбувається розпаА політичної філософії на теорію і практику. Перша, завдяки все більш широкому застосуванню критеріїв науковості, запозичених з природознавства, все більше перетворюватиметься на зразковий позитивізм, Аруга - на безпринципний сервілізм 
політичних радників. Як про це пише Штраус, «ставши найвищим предметом філософії, практика переста^а бути власне практикою, тобто турботою про agenda. Повстання проти гегеліанства з боку К’еркегора та Ніцше, якшо вони зараз справляють сильний вплив на громаАську Аумку, зАаються, отже, спробами відновити можливість практики, тобто АюАського життя, у якого є значуще і невизначене майбутнє» [Штраус, 2007, с. 304-305].

Звичайно, Штраус не покладає віАповіАальність за розрив з класичною політичною філософією на одного тільки Гегеля. Історицизм, вважає він, народився і виріс завдяки зусил ям багатьох філософів Нового Часу: Н. Маккіавелмі, Ф. Бекона, Т. Гоббса, Р. Аекарта, Б. Спінози, Ж.-Ж. Руссо. Безумовно, вчення Гегеля також не презентує в повному обсязі всі версії сучасного історицизму, тому Штраус час віА часу звертається Ао критики інших представників історицизму: у зимовому семестрі 1956 року він прочитав курс «Історицизм і сучасний релятивізм», присвячений Колмінгвуду і Ніцше.

Але історицизм немислимий без свого ключового елемента, без прогресизму, і саме Гегель Аля Штрауса є тим апологетом прогресизму, завдяки якому в політичному мисленні затвердився такий погАяА на історичний процес, згіАно з яким іАеальний порядок поступово виникає в процесі історичного руху зі сліпих суб’єктивних Аій i неусвіАомлюваних цілей. 3 цього уявлення про єАність і прогрес в історії виросло гегелівське поняття всесвітньої історії. Штраус ретельно розглядає це поняття і знаходить у ньому цілий клубок протиріч i труднощів. Перше 3 них стосується питання про співвіАношення емпіричної історії і філософії історії: філософська всесвітня історія має справу з емпіричним матеріалом, Ао якого вона звертається як «мислячий розгляА» (Гегель). Чи не означає це, що гегелівська всесвітня історія є продуктом застосування схем і категорій, апріорних щодо власне історичного матеріалу? Нам відома віАповіль Гегеля на подібні звинувачення: «... ми маємо розглядати історію в тому вигляді, в якому вона існує: ми повинні виробляти наше досліАження історично, емпірично; між іншим, ми не повинні Аати обдурити себе історикам-фахівцям, тому що вони, особливо користуються значним авторитетом німецькі історики, роблять те, чим вони дорікають філософам, а саме Аопускають апріорні вигадки в історії [Гегель, 1935, с. 11]. I Штраус пілтверджує: Гегель Аійсно прагне до емпіричного Аослідження історії. Втім, коли Гегель наполягає на перетворенні історичного АосвіАу, на віАліленні в ньому істотного віА випадкового й неважливого, він помічає, що критерії такого розрізнення не є очевидними та зрозумілими. У цьому разі на допомогу Гегелю приходить теза про те, що істинний смисл історичних фактів можна знайти мише в майбутньому. Гегелівська сова Мінерви, що вилітає в сутінки, є справжнім символом фіналізму гегелівської філософії, яка оцінює історичні факти тільки 3 погляду їх важливості Аля історичного прогресу. Отже, робить висновок Штраус, гегелівська філософія історії є неповною і некоректною, а іноді Гегель змушений просто викривляти емпіричні факти, пропускати в досліАженні і замовчувати ті культури та епохи, які не вкцадаються в його схему прогресивного історичного розвитку.

Штраус звертає увагу також на те, що гегелівська філософія історії непосліловна в застосуванні свого історицистського принципу і не застосовує цей принцип Ао розгляАу себе самої. За Гегелем, історичний процес завершується в той момент, коли з'яв яятьься його власна система. Штраус вважає, що ця особливість гегелівської філософії має величезне значення для розуміння історицизму взагалі: «Припущення якогось абсолютного моменту в історії $є$ необхіАним Аля історицизму. У цьому віАношенні історицизм таємно сліАує класично створеному Гегелем прецеденту. Гегель вчив, що кожна філософія $\epsilon$ концептуальним вираженням духу свого часу, i, тим не менш, він стверджував абсолютну істину своєї системи філософії, приписуючи абсолютний характер своєму часу; він припустив, що його час був кінцем історії i, отже, абсолютним моментом» [Штраус, 2007, с. 34]. Отже, фіналізм гегелівської філософії не є випадковою помилкою іï творця, він потрібен Гегелю Аля того, щоб обгрунтувати претензії історицистської ідеології на особливе місце в історії іАей. 
Крім того, Штраус покцаАає на Гегеля віАповіАальність за ті негативні явища в сучасному світі, націонал-соціалізм і марксизм, які, на його Аумку, є спадкоємцями «німецького нігілізму» [Strauss, 1999]. Він стверджує: «Помилки комунізму були вже помилками Гегеля і навіть Канта» [Штраус, 2000, с. 49]. Штраус звинувачує Гегеля в тому, що той зАійснив найбільш небезпечний варіант секуляризації політичного мислення - він трансформував християнство, яке в гегелівькому розумінні перестало бути вірою, а стало формою знання, що позбавило всі християнські цінності універсального змісту. Штраус вказує, що гегелівське неприйняття (або секуляризація) віри і пов'язана з ним концепція особ̆истого Бога призвели Ао остаточного забуття теологіко-політичної проб̆еми.

Теологіко-політичною проблемою Штраус називає питання про те, чи можуть Аюди отримати те знання про благо, без якого вони не можуть керувати своїм життям, індивідуальним і колективним, самостійно і без сторонньої допомоги, або ж це неможливо без божественного одкровення. 3 віАповіАі на це питання випливає ще одне ускладнення: чи є, враховуючи множинність Аюдських думок і бажань, життя філософії кращим, ніж життя віри? Пропаганда філософського життя Гегелем через його синтез віри і розуму була заснована, вважає Штраус, на ігноруванні цього питання. Гегель, так само, як і раніше Гоббс, ретельно очистив сферу політичного віА релігійних елементів і в такий спосіб пілірвав уявлення класичної політичної філософії про Аюдину як про істоту, за своєю природою релігійну і тому - моральну. ПіА час полеміки з Кожевом («Ще раз про "Гієрона" Ксенофонта») Штраус зауважує: «Вчення Гегеля є незрівнянно більш витонченим, ніж вчення Гоббса, але воно $\epsilon$ не менш штучною спорудою. Обидві Аоктрини конструюють АюАське суспільство, віАштовхуючись віА хиб̆ного припущення про те, що Аюдина як така може бути помисленою як істота, позбавлена свідомості священних обмежень, або як істота, якою рушить єАина спрага визнання» [Штраус, 2006, с. 297]. У позиції Гегеля щодо релігії Штраус знаходить приховану суперечливість, або принаймні двозначність: з одного боку, Гегель вважас, що релігія, особливо протестантизм, є найважливішим елементом сучасної Аержави, але 3 іншого боку, він недооцінюе важливість релігії як соціального інституту, надаючи громадянство не тільки протестантам. Гегель передбачає, що розум у формі філософії міг би зайняти місце релігії як об’єАнуючої сили суспільства, але це явно віАноситься тільки Ао мислячої меншості. А що можна сказати про переважну більшість, про тих, хто не є філософами? У своєму курсі 1958 року Штраус запитує: «Як же ці мюди, які можуть прийняти участь в розумі тільки через релігію, можуть стати причетними Ао розуму, коли релігії як найпотужнішої соціальної сили більше вже не існує? Подумайте про той простий факт, що, якщо газета замінює щоденну молитву, вона повністю спустошує суспільство. У Гегеля немає віАповіАі на це питання» [Штраус, 2007, с. 83].

Ще один напрямок критики Гегеля Штраусом пов'язаний з вельми специфічним елементом його власної теорії, з концепцією «письма між рядків». Аео Штраус розробив концепцію особливого виАу письма, яку розгорнуто преАставив в роботах «ПересліАування і мистецтво письма» [Strauss, 1952] і «Про забуте мистецтво письма» [Strauss, 1954]. Суть концепції полягає в тому, що філософ, як вважає Штраус, завжАи знаходиться у віАношенні протистояння щодо будь-якого політичного режиму, будь-яка істинна філософія є філософією політичною, а філософ завжди є критиком влади і держави, навіть якщо це і не входило в його плани. Аля того, щоб не зазнати репресій з боку Аержави і виявляючи повагу Ао Аумок суспільства, філософ змушений приховувати свої іАеї в особливому езотеричному Аискурсі. Як пише Штраус, «філософи або вчені, які АОтримуються цього піАходу Ао розуміння зв'язку філософії або науки і суспільства, змушені використовувати своєріАну манеру письма, яка б Аозволила їм відкривати небагатьом обраним те, що вони вважають істиною, не підааючи водночас небезпеці безумовну відланість більшості думок, на яких грунтується суспільство. Вони розрізняють істинне - езотеричне вчення, і суспільно корисне - екзотеричне вчення; тоді як екзотеричне вчення має бути Аоступним кожному читачеві, езотеричне вчення 
розкривається Аише переА Ауже уважними і добре піАготовленими читачами, та й то після Аовгого i зосередженого навчання» [Strauss, 1954, p. 64]. Езотерична манера письма в певному сенсі є тим критерієм, який вілрізняє філософа віА нефілософа, і всі великі філософи зараховуються Штраусом до езотериків. Гегель віАкрито виступав проти будь-якого езотеризму у філософії і в такий спосіб, вважає Штраус, ініціював процес переродження філософії в позитивістську науку, а політичної філософії зокрема - ще й в сервільну іАеологічну пропаганду. ПіАставою Аля такого твердження Штрауса стала гегелівська критика концепції таємного вчення Пцатона в «Нарисі історії класичної філософії» В. Г. Теннемана. Гегель писав: «Виходить так, ніби філософ володіс своїми Аумками так само, як зовнішніми предметами. Але філософська ідея є чимось зовсім іншим, і не цюдина володіс нею, а, навпаки, вона володіє Аюдиною. Якщо філософи висловлюються про філософські питання, вони неодмінно мають сліАувати своїм іАеям; вони не можуть заховати іх у кишеню. Навіть у тих випадках, коли вони говорять 3 Аеякими АюАьми зовні, іАея все ж міститься в тому, що вони висловАюють, якщо тільки воно не є беззмістовним. А^я передачі якої-небудь зовнішньої події потрібно небагато, але Аля повідомлення ідеї потрібне вміння. Вона завжАи залишається чимось езотеричним, і філософи ніколи не Аають виключно екзотеричне вчення. Все це поверхові уявлення» [Гегель, 1932, с. 132]. Штраус вказує на це висловлювання Гегеля як на свіАоцтво його віАхоАу віА суто філософської позиції.

Звичайно, було б Аивно очікувати віА такого тонкого мислителя, як Штраус, пласкої однозначності при оцінці великого філософа. Він визнає, що Гегель став, як мінімум, Аругим за значимістю після Ж.-Ж. Руссо мислителем Аругої хвилі модернізації і практично єАиним, хто не впав у своїй політичній філософії до аморалізму. Штраус стверджує, що всесвітньо-історична особистість у Гегеля, незважаючи на безчинства, які часто чинить такий індивіА, більш моральна, ніж індивіА Макіавеллі. Тому Штраус і казав у мекціях 1958 року, що Гегель, на його Аумку, ніколи б не виправдав Сталіна та Гітлера [Strauss, 2019b, p. VIII]. Без сумніву, Штраус розумів своєріАний історично проміжний характер гегелівської політичної філософії, яка все ще зберігала в окремих моментах зв’язок з класичною політичною філософією, і вілрізняв ї̈ віА вчень Аільтея і Ніцше, які зі свого боку також критикували Гегеля, але цього разу - за його начебто недостатньо радикальний історицизм.

Проаналізувавши основні критичні аргументи, спрямовані Аео Штраусом проти гегелівської політичної філософії, ми Аоходимо висновку, що ця критика є важливою частиною власної філософіï Штрауса, а саме його проєкту реставрації класичної політичної філософії. Аля цього йому треба було осмислити суть сучасної політичної науки, яка народилася в рамках проєкту модерну, одним з головних ідеологів якого і був, на Аумку Штрауса, Гегель.

\section{СПИСОК ВИКОРИСТАНИХ АЖЕРЕА}

Гегель Г. В. Ф. Аекции по истории философии. Книга вторая / пер. с нем. Б. Г. Столпнера. Сочинения: в 14 т.; т. 10. М.; А.: Партийное изАательство, 1932. 490 с.

Гегель Г. В. Ф. Философия истории / пер. с нем. А. М. Водена. Сочинения: в 14 т.; т. 8. М.; А.: Партийное изАательство, 1935. 468 с.

Карівець I. В. Аео Штраус про читання та тлумачення езотеричних текстів. Паддxami. 2010. Вип. 5. URL: https://7promeniv.com.ua/naukovi-doslidzhenniav/mizhdystsyplinarnyi-zhurnal/66-2010-vypusk-4/86-ihor-karivets-leo-shtraus-pro-chytannia-tatlumachennia-ezoterychnykh-tekstiv.html.

Шевчук А. Проблема віАродження класичної традиції в сучасній політичній філософіі: Ханна Аренлт, Аео Штраус. Наукові записки Науіонального університету «Острозька академіял. Сер.: Філософія. 2010. Вип. 6. С. 12-19.

Штраус $\Lambda$. Введение в политическую философию / пер. с англ. М. Фетисова. М.: Аогос; Праксис, 2000. 365 с. 
Штраус $\Lambda$. Естественное право и история / пер. с англ. Е. ААлера, Б. Путько. М.: Водолей Publishers, 2007. 312 с.

Штраус $\Lambda$. О тирании / пер. с англ. и Аревнегреч. А. А. Россиуса, пер. с франц. А. М. Руткевича. СПб.: ИзА.-во С.-Петерб. ун.-та, 2006. 328 с.

Altmann W. Leo Strauss on "German Nihilism". Learning the Art of Writing. The Journal of the History of Ideas. 2007. Vol. 68. No.4. pp. 587-612. DOI: https://doi.org/10.1353/jhi.2007.0032.

Fuller T. Allies, not Enemies. The Review of Politics. 2014. Vol. 76. Issue 4. pp. 674-676. DOI: https://doi.org/10.1017/S0034670514000643.

Kojève A. Le Concept, le Temps et le Discours. Paris: Éditions Gallimard, 1990. 320 p.

MacDonald S., Craig B. Recovering Hegel from the Critique of Leo Strauss: The Virtues of Modernity. Lanham: Lexington Books, 2014. 151 p.

Pangle T. Leo Strauss: An Introduction to His Thought and Intellectual Legacy. Baltimore: The Johns Hopkins University Press, 2006. 200 p.

Pippin R. Being, Time, and Politics: The Strauss-Kojève Debate. History and Theory. 1993. Vol. 32. No. 2. pp. 138-161. DOI: https://doi.org/10.2307/2505349.

Rosen S. Leo Strauss in Chicago. Daedalus. 2006. Vol. 135. No. 3. pp. 104-113. DOI: https://doi.org/10.1162/daed.2006.135.3.104.

Schlie M. Words without Desire: Strauss, Hegel, and Political Violence. The Review of Metaphysics. 2013. Issue 66. pp. 519-544.

Strauss L. German Nihilism. Interpretations. 1999. Vol. 26. No.3. pp. 353-378.

Strauss L. Lectures on Hegel's Political Philosophy / Ed. by P. Franco. Chicago: Department of Political Science, The University of Chicago, 2019. 261 p.

Strauss L. Leo Strauss on Hegel / Ed. by P. Franco. Chicago: University of Chicago Press, 2019. 384 p. DOI: https://doi.org/10.7208/chicago/9780226640716.001.0001.

Strauss L. On a Forgotten Kind of Writing. Chicago Review. 1954. Vol. 8. No. 1. pp. 64-75. DOI: https://doi.org/10.2307/25293010.

Strauss L. Persecution and the Art of Writing. Chicago: University of Chicago Press, 1952. pp. 22-37.

\section{Прокопенко Володимир Володимирович}

Аоктор філософських наук, професор кафедри теоретичної і практичної філософії імені професора Й. Б. ШаАа

Харківський національний університет імені В. Н. Каразіна

майдан Свободи, 6, Харків, 61022

E-mail: Pvlad99@gmail.com

ORCID: https://orcid.org/0000-0001-5816-3505

Стаття наАійшла до редакції: 09.11.2020

Схвалено Ао Аруку: 27.11.2020

\section{LEO STRAUSS: A CRITIQUE OF HEGEL'S POLITICAL PHILOSOPHY}

\section{Prokopenko Vladimir V.}

D.Sc. in Philosophy, Professor of the Department of Theoretical and Practical Philosophy named after Professor J. B. Schad V. N. Karazin Kharkiv National University

6, Svobody sqr., 61022, Kharkiv, Ukraine

E-mail PVlad99@gmail.com

ORCID: https://orcid.org/0000-0001-5816-3505 


\begin{abstract}
The article is devoted to Leo Strauss's critique of Hegel's political philosophy. The author holds this topic relevant in the context of the crisis of modern political science. To understand the causes and nature of this crisis, it is necessary to pay attention to alternative philosophical and political theories of the XX century. Leo Strauss's philosophy of politics is just such an alternative theory. Strauss made a radical critique of modern political philosophy, which he saw as an important part of the project of modern civilization. Strauss stresses that Hegel became one of the most prominent philosophers who participated in the creation of modern science and the modern world. The author considers the main critical arguments of Strauss, evaluates their validity and their significance for the Straussian conservative revolution in philosophy. The author pays special attention to the question of Hegel's role in the break with classical political philosophy. Strauss accused Hegel that he had taken all the major steps that led to this rupture. Hegel, according to Strauss, secularized political thinking, which led to the loss of universal Christian values. The consequence of this secularization was the dominance of positivism in political philosophy. Hegel's philosophy of history, according to Strauss, is relativism. Hegel's historicism and progressivism are contradictory and inconsistent. Strauss also accuses Hegel of abandoning the philosophical esoteric art of writing. The article draws attention to the fact that Strauss recognized the importance of Hegel as an outstanding thinker of his time. Strauss viewed Hegel's philosophy as a kind of intermediate link between classical philosophy and modern positivism. The author concludes that for Strauss the critique of Hegel's political philosophy became an important element of his project of restoration of classical political philosophy. The article uses little-known materials from Strauss's lectures in 1958 and 1965.
\end{abstract}

Keywords: political science, classical political philosophy, historicism, relativism, progressivism, finalism, writing between the lines.

\title{
REFERENCES
}

Altmann, W. (2007). Leo Strauss on “German Nihilism”. Learning the Art of Writing. The Journal of the History of Ideas, 68(4), 587-612. DOI: https://doi.org/10.1353/jhi.2007.0032.

Fuller, T. (2014). Allies, not Enemies. The Review of Politics, 76(4), 674-676. DOI: https://doi.org/10.1017/S0034670514000643.

Hegel, G. W. F. (1935). Philosophy of History. (A. M. Voden, Trans.). In G. W. F. Hegel, The Collected Writings in 14 Volumes (Vol. 8). Moscow; Leningrad: Publishing House Partiynoe. (Original work published 1837). (In Russian).

Hegel, G. W. F. (1932). Lectures on the Philosophy of History. (B. G. Stolpner, Trans.). In G. W. F. Hegel, The Collected Writings in 14 Volumes (Vol. 10). Moscow; Leningrad: Publishing House Partiynoe. (Original work published 1837). (In Russian).

Karivets, I. V. (2010). Leo Strauss On Reading and Interpretation of Esoteric Texts. Paddkhati, 5. Retrieved from https://7promeniv.com.ua/naukovi-doslidzhenniav/mizhdystsyplinarnyi-zhurnal/66-2010-vypusk-4/86-ihor-karivets-leo-shtraus-prochytannia-ta-tlumachennia-ezoterychnykh-tekstiv.htm. (In Ukrainian).

Kojève, A. (1990). Le Concept, le Temps et le Discours. Paris: Éditions Gallimard. (In French).

MacDonald, S., \& Craig, B. (2014). Recovering Hegel from the Critique of Leo Strauss: The Virtues of Modernity. Lanham: Lexington Books.

Pangle, T. (2006). Leo Strauss: An Introduction to His Thought and Intellectual Legacy. Baltimore: The Johns Hopkins University Press.

Pippin, R. (1993). Being, Time, and Politics: The Strauss-Kojève Debate. History and Theory, 32(2), 138-161. DOI: https://doi.org/10.2307/2505349.

Rosen, S. (2006). Leo Strauss in Chicago. Daedalus, 135(3), 104-113. DOI: https://doi.org/10.1162/daed.2006.135.3.104.

Schlie, M. (2013). Words without Desire: Strauss, Hegel, and Political Violence. The Review of Metaphysics, 66, 519-544.

Shevchuk, D. (2010). The Problem of Revival of Classical Tradition in Contemporary Political Philosophy: Hannah Arendt, Leo Strauss. Scientific Notes of the National University "Ostroh Academy". Ser.: Philosophy, 6, 12-19. (In Ukrainian). 
Strauss, L. (2000). An Introduction to Political Philosophy. (M. Fetisov, Trans.). Moscow: Logos; Praxis. (Original work published 1959). (In Russian).

Strauss, L. (2006). On Tyranny. (A. A. Rossius \& A. M. Rutkevich, Trans.). Saint-Petersburg: SaintPetersburg University Publishing House. (Original work published 1947). (In Russian).

Strauss, L. (2007). Natural Right and History. Moscow: Vodolei Publishers. (Original work published 1953). (In Russian).

Strauss, L. (1952). Persecution and the Art of Writing. Chicago: University of Chicago Press.

Strauss, L. (1954). On a Forgotten Kind of Writing. Chicago Review, 8(1), 64-75. DOI: https://doi.org/10.2307/25293010.

Strauss, L. (1999). German Nihilism. Interpretations, 26(3), 353-378.

Strauss, L. (2019a). Leo Strauss on Hegel. (P. Franco, Ed.). Chicago: University of Chicago Press. DOI: https://doi.org/10.7208/chicago/9780226640716.001.0001.

Strauss, L. (2019b). Lectures on Hegel's Political Philosophy. (P. Franco, Ed.). Chicago: Department of Political Science, The University of Chicago.

Article arrived: 09.11.2020

Accepted: 27.11.2020 